\title{
THE VOLUME AND DYNAMICS OF DOMESTIC EXPENDITURES ON RESEARCH AND DEVELOPMENT IN THE EUROPEAN UNION
}

WIELKOŚĆ I DYNAMIKA KRAJOWYCH WYDATKÓW NA BADANIA I ROZWÓJ W UNII EUROPEJSKIEJ

Jerzy Baruk, PhD, Eng.

Retired research and teaching staff member of Maria Curie-Skłodowska University in Lublin, Faculty of Economics,

Institute of Management

PI. M. Curie-Skłodowskiej 5, 20-031 Lublin, Poland

jerzy.baruk@poczta.onet.pl •ORCID 0000-0002-7515-0535

DOl: 10.2478/minib-2020-0025

\section{ABSTRACT}

In the article, whose construction is of theoretical and empirical nature, the author attempted to achieve the following objectives: 1) identification and critical assessment of expenditures on research and development (GERD index), expressed in euro per inhabitant, incurred by statistical units concentrated in the sectors: business enterprises, government, higher education, private non-profit organizations and jointly in all sectors in countries members of the European Union. The level and dynamics of these expenditures are treated as an indirect measure of senior management's involvement in creating R\&D policy and efficient management in R\&D phases; 2) an attempt to verify theses that R\&D expenditures are variable and diversified in EU Member States, which indicates the lack of a rational R\&D policy focused on the systematic generation of new knowledge materialized in innovations providing customers the expected value in a systemic way; 3 ) developing models of innovative R\&D activities management. To develop the article, research methods are used, such as: critical-cognitive analysis of literature, statistical-comparative analysis of Eurostat's empirical secondary material, projection method. The level of the GERD meter indicates a significant differentiation of R\&D expenditure in individual sections of the analysis. The member states of the old EU had relatively higher outlays for this purpose compared to the new member states.

Key words: research and development activity, innovation, statistical unit, expenditures, knowledge, management 


\section{ABSTRAKT}

Cele artykułu, którego konstrukcja ma charakter teoretyczno-empiryczny, sprowadzają się do: 1) identyfikacji i krytycznej oceny wydatków na badania i rozwój (wskaźnik GERD), wyrażonych w euro na jednego mieszkańca, poniesionych przez jednostki statystyczne skupione w sektorach: przedsiębiorstw, rządowym, szkolnictwa wyższego, prywatnych organizacjach non profit oraz łącznie we wszystkich sektorach w państwach członkowskich Unii Europejskiej (poziom i dynamikę tych nakładów potraktowano jako pośrednią miarę zaangażowania wyższego kierownictwa w kreowanie polityki $B+R$ i sprawnego zarządzania fazami $B+R$ ); 2) próby weryfikacji tezy, że nakłady na $B+R$ są zmienne i zróżnicowane w państwach członkowskich $U E$, co wskazuje na brak racjonalnej polityki $B+R$ ukierunkowanej na systemowe generowanie nowej wiedzy materializowanej w innowacjach dostarczających klientom oczekiwaną wartość w systemowy sposób; 3) skonstruowania modeli innowacyjnego zarządzania działalnością B+R. Do opracowania artykułu wykorzystano następujące metody badawcze: analizę krytyczno-poznawczą piśmiennictwa, analizę statystyczno-porównawczą wtórnego materiału empirycznego Eurostatu, metodę projekcyjną. Poziom miernika GERD wskazuje na znaczne zróżnicowanie nakładów na $B+R$ w poszczególnych przekrojach analizy. Państwa członkowskie starej UE cechowały się względnie wyższymi nakładami na ten cel w porównaniu z nowymi państwami członkowskimi.

Słowa kluczowe: działalność badawczo-rozwojowa, innowacja, jednostka statystyczna, nakłady, wiedza, zarządzanie

JEL: 023; 030; 032; 038

\section{Introduction}

One of the basic factors in the development of every economy, region, business entities is innovation, therefore every statistical unit (observation unit for which statistical data are collected and compiled) (Oslo Manual, 2018, p. 180) should strive for excellence in their systematic creation and implementation in all areas of its operation, as well as in relations with the entities of the task environment with particular emphasis on customers (Griffin, 2007, p. 76). Excellent innovation organizations are characterized by the following characteristics (Peters and Waterman, 2000, pp. 45-48; Nguyen and Nhat-Hanh Le, 2019, p. 298): 1) willingness to act, 2) close relationships with customers, 3) autonomy and entrepreneurship, 
4) efficiency achieved through people, 5) active commitment and valuedriving, 6) adherence to one's domain, 7) simple form and few administrations, 8) a combination of ease and rigidity.

The basic condition for increasing the innovativeness of statistical units is their ability to conduct research and development activity (R\&D) independently or to systematically use the results of such activity of other statistical units (purchases). There is also a possibility of another scenario based on the policy of joint R\&D work with other organizations. Following the indicated scenarios favors the growth of knowledge resources necessary for the implementation of innovation creation processes and their implementation in particular areas of business activity, in shaping relationships with customers. Such a finding results from the very definition of innovative activity treated as a set of activities of scientific (research), technical, organizational, financial and commercial nature, leading to the development and implementation of new or significantly improved products and processes (Oslo Manual, 2018, p. 68).

A prerequisite for creating and implementing innovations, especially strategic ones, is new knowledge or the ability to recombine the knowledge possessed - in the case of improvement innovations (Xie, Hall, McCarthy, Skitmore, and Shen, 2016, p. 70). Creators and holders of knowledge are properly prepared people - people of knowledge who, under favourable conditions, are able to generate such knowledge in a systemic way. These opportunities arise within the framework of activities (R\&D) organized and conducted at all levels of the economic structure, but not by all statistical units. The importance of $R \& D$ activity in the evolution of each organization is unquestionable, especially in the context of knowledge-based economy (Skrodzka, 2015, p. 114). The main feature of such an economy is the ability to systemically produce, store, update, disseminate and use knowledge in innovation creation processes. These processes make up the knowledge and innovation management system (Arendra, Putri, Rumamby, and Mericia, 2018, p. 18).

In knowledge-based economy, knowledge is becoming a key factor for development, wealth creation and employment, while human capital is a source of creativity and innovation using information and communication technologies. Thus, the organised creation of knowledge and its systematic use has become a key requirement leading to increased 
competitiveness of individual economies in the 21 st century. It constitutes an important stage in the process of development of economic entities, regions and entire societies (Knowledge-based economy, p. 87). It can also be stated that the knowledge-based economy is a system of consumption and production based on intellectual capital. In particular, it refers to the possibility of using scientific discoveries and basic and applied research, which is a fundamental aspect of all economic activity in the most developed countries. In the knowledge-based economy, intangible assets (employee knowledge, intellectual property) are the main asset of the organization. One of the meters of such an economy is the ability to carry out $R \& D$ activity in a systemic way (its internationalization) and the ability to rationally use its results and materialize them in product, process, organizational and marketing innovations.

In practice, $R \& D$ activity is subject to numerous restrictions for political, economic, technological, financial, organizational, social, management, cultural, etc. reasons. (Das, Verburg, Verbraeck, and Bonebakker, 2018, p. 99). The consequence of their impact is a relatively low and diverse interest of the management of statistical units in individual sectors in the systemic development of R\&D activity treated as a source of knowledge conditioning the rational course of innovative activity. Many managers are not interested in shaping a rational R\&D policy, because they do not see the benefits of such activity, they are afraid of losing their sovereign power (Bentzen, Sorensen, and Torfing, 2020, p. 3), or they think only in operational efficiency categories (Baruk, 2019, pp. 21-23; Deloitte Polska, 2016, p. 3).

The question arises how to meter the degree of involvement of heads of statistical units in the development of R\&D activities? Since one of the important factors of the increase in the management's interest in the development of $R \& D$ activity is the expenditures on this activity, it can be assumed that the amount of these expenditures per one inhabitant and their dynamics can be a determinant of the management's involvement in the systemic development of R\&D work in statistical units. Therefore, the GERD (Gross Domestic Expenditure on R\&D) meter was used for statistical and comparative analysis of Eurostat's secondary empirical 
material, which determines the total internal expenditure on $R \& D$ conducted on the national territory in a given reporting period. GERD is the main aggregated statistical indicator used to describe the R\&D activity of a country, covering all the $R \& D$ expenditure of the country's economy, used for international comparisons of R\&D activity (Frascati Manual 2015, p. 120).

Internal expenditures on $R \& D$ are all current expenditures and gross investment expenditures incurred on fixed assets related to R\&D activity conducted in the statistical unit in a given reporting period, regardless of the source of financing. The amount of total internal outlays on R\&D performed in the territory of a given country creates an indicator - gross national expenditure on research and development (GERD) (GUS, 2018, p. 15).

The analysis examined the development of this meter in 2014-2018 with respect to the European Union (EU) as a whole, old and new member states, including Poland.

The publication attempts to achieve the following goals:

- identification and critical assessment of R\&D expenditures (GERD indicator), expressed in euro per capita, incurred by statistical units gathered in the following sectors: business, government, higher education, private non-profit organizations, and jointly in all sectors. The level and dynamics of these expenditures are treated as an indirect meter of senior management commitment to R\&D policy-making and efficient management of R\&D phases;

- an attempt to verify the thesis that $R \& D$ expenditures are variable and diverse in the EU Member States, which indicates the lack of a rational R\&D policy aimed at the systemic generation of new knowledge materialized in innovations providing customers with the expected value in a systemic way;

- proposing models of innovative management of R\&D activity.

The publication was prepared using the following research methods: critical-cognitive analysis of literature, statistical and comparative analysis of secondary empirical material from Eurostat, projection method. 


\section{The essence of R\&D activity. Model of R\&D management}

R\&D activity, as a specific type of creative activity, must be (Frascati Manual 2015, p. 30):

- innovative - oriented towards new discoveries,

- creative - based on original, unobvious concepts and hypotheses,

- unpredictable - uncertain as to the final result and cost, including the time spent,

- methodical - conducted in a planned manner (with a specific R\&D project objective and source of financing),

- transferable or reproducible - leading to results that can be reproduced.

The R\&D activities consist of (Frascati Manual 2015, p. 30; Ecker, van Triest, and Williams, 2011, p. 910; Baruk, 2019, p. 7):

- basic research, including experimental or theoretical work undertaken primarily to acquire new knowledge of the foundations of phenomena and observable facts, with no focus on specific application or use;

- applied research, including original research undertaken in order to acquire new knowledge; however, they are primarily aimed at a specific, practical purpose;

- development work, including work undertaken in a methodical manner, based on knowledge acquired through research and development activities and practical experience and producing additional knowledge, aimed at producing new products or processes or improving existing products or processes.

The indicated sets of activities are interdependent in terms of both process and result, therefore they should be covered by the processes of systematic, rational management by managers capable of creating a vision of the organization's development, detailing it in the R\&D and innovation strategy, related to production and marketing strategies. The management of the R\&D sphere should be aimed at synchronizing the acquisition of new knowledge and its rational transformation into new products (products or services). The idea of such management is presented in Figure 1. 


\section{Figure 1. R\&D management model}

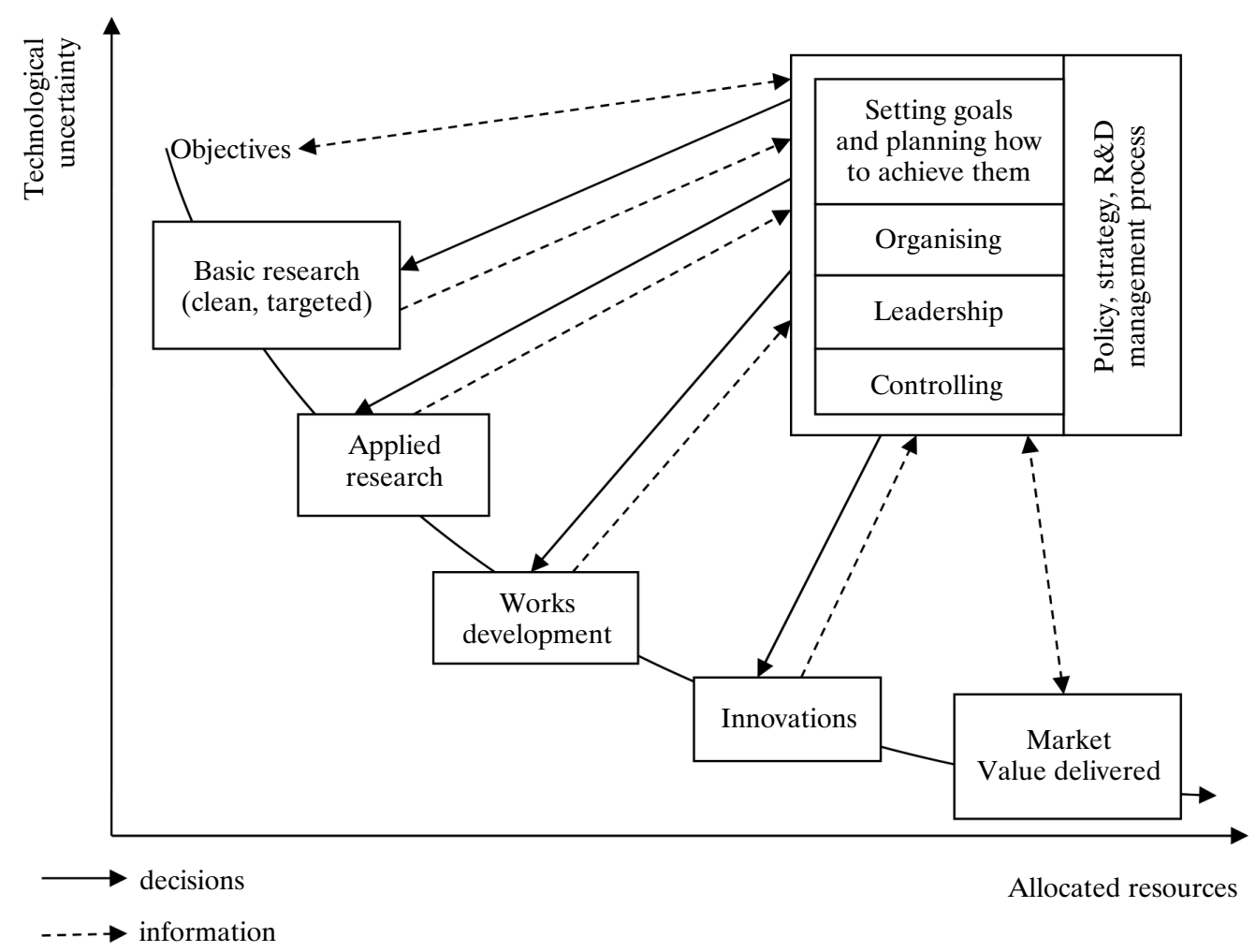

Source: own elaboration.

Management in accordance with the assumptions of the presented concept may facilitate the social organization of knowledge and its use through the implementation of management functions including: 1) creating objectives for basic, applied and developmental research, resulting in the acquisition of new knowledge, 2) planning the ways of achieving these objectives, 3) organizing conditions conducive to the achievement of objectives in the structural and process sense, 4) acquiring human resources and motivating them to achieve the partial objectives that make up a specific phase of the R\&D process, 5) controlling the compliance of practical activities with previously established objectives and plans, possibly correcting deviations. These functions are repeated in relation to 
subsequent phases of the R\&D activity after taking into account their content.

The first logical management action should be to establish an R\&D strategy to effectively address emerging internal or external problems. Such a strategy should result in objectives to be achieved in the next phases of R\&D works. The efficiency of the course of individual phases requires finding answers to the following questions: 1) what is the problem to be solved, 2) what knowledge is necessary to solve the problem?, 3) how to acquire this knowledge?, 4) what resources should be engaged for efficient acquisition of knowledge?, 5) how should the acquired knowledge be used in the subsequent phases of the R\&D process?, 5) how should the information and decision-making processes proceed in order to efficiently manage individual phases of $\mathrm{R} \& \mathrm{D}$ ?

It should be stressed that each phase of the $R \& D$ process requires a different approach to management due to the specificity of these phases (Suomala and Jokioinen, 2003, p. 214). The creative and holistic approach of the chief executive of each statistical unit to such management is justified (Heij, Volberda, Van den Bosch, and Hollen, 2019, p. 281). This category of innovation can be defined as the first, conscious application of new ways of performing management functions, new management methods, leading to increased efficiency in performing these functions, resulting in beneficial transformations in the social system of the organization, increasing the integration of individual functional areas and the ability to acquire knowledge and materialize it in new products, processes and customer relationships. These changes, characterized by novelty, should result in the improvement of effectiveness of functioning and development of the organization and individual functional areas. The consequence of such an approach to the management of individual phases of R\&D work should be an innovation capable of satisfying specific internal or market needs (providing value). In every situation the information and decision making processes must be based on the results of the diagnosis of the current state of the statistical unit and elements of its environment, with particular emphasis on actual and potential customers. The manifestation of such diagnosis may be a statistical-comparative analysis of expenditures on research and development activities incurred in a given time. 


\section{The development of the GERD meter in all sectors}

The first cross-section of the analysis is the level and dynamics of national R\&D expenditures (GERD) incurred in all sectors in the European Union (EU) Member States and the United States per capita. As Table 1 shows, on average, in the EU, domestic R\&D expenditures gradually increased from 562.1 euro/inhabitant in 2014 to 656.5 euro/inhabitant in 2018. Thus, the level of this meter increased by $16.8 \%$. In terms of value and dynamics, the level of national spending on R\&D varied across Member States. Among the old Member States, the highest expenditures per capita were incurred in Sweden. In 2014 it amounted to 1,411.3 euro and was 849.2 euro higher than the EU average. In the following years, these expenditures gradually increased to 1,615 euro in 2017. However, in 2018 a decrease in the analyzed meter to 1,540.7 euro was recorded. Outside Sweden, the relatively high national R\&D expenditures per capita of more than 1,000 euro were characterized by a relatively high level: Denmark, Austria, Finland, Germany, Luxembourg and Belgium - but only in 2017-2018. In Denmark, Austria and Germany, GERD was not only characterized by a relatively high level, but also by successive growth dynamics over the analyzed period of time. Compared to 2014, the growth rate in 2018 was at a high level: $14.9 \%$ in Denmark and Austria; 21.3\% in Germany.

At the opposite end of the scale on the other side were: Greece, Portugal, Spain and Italy. In these countries, on average, in the years 2014-2018, the internal R\&D spending per capita was on average: 169.5 euro in Greece; 235.7 euro in Portugal; 293.4 euro in Spain and 380.8 euro in Italy. Compared to 2014, 2018 saw an increase of 48.7\% in Greece, 24.9\% in Portugal, $16.2 \%$ in Spain and $13.4 \%$ in Italy.

Large differences in the level and dynamics of the meter were observed among the new Member States. The countries that stood out positively were Slovenia, the Czech Republic and Estonia. In Slovenia, the average per capita $R \& D$ spending in the years $2014-2018$ was 438.8 euro with a decrease from 432.9 euro in 2014 to 388.4 euro in 2017 . In 2018, expenditures were lower by 0.1 euro/inhabitant. 
Table 1. National spending on research and development (GERD) in all sectors in 2014-2018 (in euro per capita)

\begin{tabular}{|c|c|c|c|c|c|}
\hline \multirow{2}{*}{ Specification } & \multicolumn{5}{|c|}{ The amount of expenditure in years: } \\
\hline & 2014 & 2015 & 2016 & 2017 & 2018 \\
\hline European Union (EU-28) & 562.1 & 594.1 & 598.0 & 624.2 & $656.5(\mathrm{p})$ \\
\hline \multicolumn{6}{|l|}{ Old EU-15 Member States: } \\
\hline Austria & $1,207.7$ & $1,223.0$ & $1,279.9$ & $1,286.9$ & $1,388.1(\mathrm{p})$ \\
\hline Belgium & 854.3 & 900.4 & 959.5 & $1,045.5$ & $1,115.0(\mathrm{p})$ \\
\hline Denmark & $1,376.2$ & $1,473.7$ & $1,534.2$ & $1,551.4$ & $1,580.9(\mathrm{p})$ \\
\hline Finland & $1,194.6$ & $1,109.5$ & $1,080.0$ & $1,121.7$ & 1167.7 \\
\hline France & 724.2 & 749.9 & 745.1 & 757.7 & $773.5(\mathrm{e})$ \\
\hline Greece & 136.2 & 156.9 & 162.7 & 189.3 & $202.5(\mathrm{p})$ \\
\hline Spain & 275.6 & 283.6 & 285.5 & 302.2 & 320.3 \\
\hline The Netherlands & 788.4 & 810.4 & 833.0 & 857.0 & $974.8(\mathrm{p})$ \\
\hline Ireland & 629.9 & 669.8 & 686.2 & 765.3 & 769.1 \\
\hline Luxembourg & $1,145.8$ & $1,176.5$ & $1,198.1$ & $1,220.1$ & $1,208.3(\mathrm{p})$ \\
\hline Germany & 1043.1 & $1,093.4$ & $1,121.7$ & $1,206.4$ & $1,265.4(\mathrm{e})$ \\
\hline Portugal & 214.1 & 215.4 & 231.0 & 250.7 & $267.5(\mathrm{p})$ \\
\hline Sweden & $1,411.3$ & $1,504.3$ & $1,537.0$ & $1,615.0$ & 1540.7 \\
\hline Great Britain & 589.9 & 671.9 & 618.3 & 590.8 & $622.7(\mathrm{p})$ \\
\hline Italy & 358.3 & 364.5 & 382.0 & 392.7 & $406.4(\mathrm{p})$ \\
\hline \multicolumn{6}{|l|}{ New EU-13 Member States: } \\
\hline Bulgaria & 46.9 & 60.4 & 52.5 & 54.7 & $60.0(\mathrm{p})$ \\
\hline Croatia & 80.0 & 88.7 & 96.0 & 101.9 & $122.2(\mathrm{p})$ \\
\hline Cyprus & 104.3 & 100.7 & 116.5 & 128.9 & $134.0(\mathrm{p})$ \\
\hline Czech Republic & 294.0 & 308.4 & 280.8 & 324.5 & $377.6(\mathrm{p})$ \\
\hline Estonia & 217.9 & 230.3 & 205.4 & 231.3 & $277.2(\mathrm{p})$ \\
\hline Lithuania & 128 & 133.4 & 113.4 & 133.0 & $141.3(\mathrm{p})$ \\
\hline Latvia & 81.3 & 76.6 & 56.1 & 70.7 & $96.3(\mathrm{p})$ \\
\hline Malta & 141.0 & 162.6 & 130.3 & 143.2 & 142.6 \\
\hline Poland & 101.6 & 113.6 & 108.3 & 127.3 & $158.5(\mathrm{p})$ \\
\hline Romania & 28.8 & 39.4 & 41.4 & 48.1 & 52.5 \\
\hline Slovakia & 123.6 & 171.0 & 118.1 & 137.8 & 138.0 \\
\hline Slovenia & 431.9 & 413.5 & 393.4 & 388.4 & $431.8(\mathrm{p})$ \\
\hline Hungary & 144.7 & 153.3 & 139.5 & 170.8 & 209.8 \\
\hline USA & $1,125.3$ & $1,390.0$ & $1,442.5$ & $1,477.8$ & - \\
\hline
\end{tabular}

(p) - preliminary data (provisional)

(e) - estimated data

Source: own elaboration on the basis of Eurostat Data Explorer, https://appsso.eurostat.ec.europa.eu/nui/print.do 
In 2014, expenditure of nearly 432 euro has secured Slovenia 12th position among the Member States. The same was in 2018. In the Czech Republic, spending on R\&D was 294.0 euro per capita in 2014. In the following year it increased by 4.9 p.p., while in 2016 it decreased by 4.5 p.p. In 2017 it increased by 10.4 p.p. compared to the base year, and in 2018 by 28.4 p.p. In Estonia the average value of the GERD meter in the analyzed period was 232.4 euro/inhabitant without clear upward trends.

The lowest expenditures on R\&D were recorded in Romania and Bulgaria. On average, they amounted to 42 and 54.9 euro per capita. In Poland, the average value of the GERD meter was 121.9 euro/inhabitant. In subsequent years of the analysis, these expenditures increased slightly from 101.6 euro to 158.5 euro, except for 2016, when the analyzed meter decreased by 4.7 p.p. compared to the previous year. However, compared to the base year (2014), the meter increased by 6.6 p.p. Overall, in terms of the GERD meter, Poland was ranked 24th in 2014, 23rd in 2015, 24th in 2016 and 2017, and 20th in 2018. Among the new Member States, Poland was ranked 9th in 2014, 2016 and 2017, 8th in 2015, and 5th in 2018. It should be emphasized that, against the background of the average level of the GERD meter in the EU, Poland's achievements in this respect were very modest. In the analyzed period of time, a significant and widening gap was visible: 460.5 euro/inhabitant — in 2014, 480.5 euro/inhabitant — in 2015, 489.7 euro/inhabitant - in 2016, 496.9 euro/inhabitant - in 2017 and 498.0 euro/inhabitant — in 2018.

In terms of national R\&D spending, it was below the EU average in 2014. Greece, Spain, Portugal, Italy — among old Member States and all new Member States. Similar trends occurred in the remaining years. In general, per capita domestic $R \& D$ expenditure in the new Member States was clearly different from that in most of the old Member States.

\section{The development of the GERD meter in the enterprise sector}

The second cross-section of the analysis is the level and dynamics of national expenditure on R\&D (GERD) incurred in the enterprise sector per 
capita. In most industrialized countries, the highest share of expenditures on R\&D activity is in the business enterprises sector. The business enterprise sector includes (Frascati Manual 2015, p. 34):

- all enterprises with resident status, including not only enterprises with legal personality, regardless of the place of residence or the seat of their shareholders. This includes both private companies (listed and traded or not) and public sector companies (i.e. companies controlled by the government sector),

- unincorporated branches of non-resident enterprises which are considered to be resident and part of this sector because they produce in the given economic area in the long term,

- all resident non-commercial institutions that are manufacturers of products or services on the market or provide services for business.

As Table 2 shows, the average level of the analyzed GERD meter in the EU was: 359.5 euro/inhabitant in 2014 and it gradually increased to 382.0 euro/inhabitant in 2015 . (increase by 6.3 p.p.); to 390.9 euro/inhabitant in 2016. (an increase of 2.3 p.p. compared to the previous year); to 412.8 euro/inhabitant in 2017. (an increase of 5.6 p.p. compared to the previous year); to 438.0 euro/inhabitant in 2018 (an increase of 6.1 p.p. compared to the previous year). Thus, a few percent increase in the analyzed meter yearon-year is visible, which is a positive phenomenon.

In the Member States, this meter was at a very different level. Among the old Member States, Sweden was the leader, where in 2014 the national $R \& D$ expenditure in the enterprise sector amounted to just over 946 euro/inhabitant. By 2017, it was gradually, albeit slightly increasing to nearly 1,152 euro/inhabitant (an increase of 21.7 p.p. compared to the base year). Unfortunately, the following year saw a decrease to 1092 euro/inhabitant (down 5.2 p.p.). Denmark and Austria were also among the countries with the highest national R\&D expenditures in the enterprise sector. In Denmark in 2014 they amounted to nearly 878 euro/inhabitant. In the following years they increased slightly by 6.6 p.p. in 2015 ; by 6.7 p.p. (year-on-year) in 2016 ; by 0.5 p.p. in 2017 and by 1.3 p.p. in 2018 . 
Austria was ranked third in terms of the meter, with almost 861 euro per capita in the enterprise sector in 2014. In the years that followed, the dynamics of this expenditure was on an upward trend, up to almost 970 euro in 2018. The recorded year-on-year increases were accordingly: 1.4 p.p. in 2015; 2.9 p.p. in 2016; 0.07 p.p. in 2017 and 7.9 p.p. in 2018.

At the opposite end of the scale were Greece, Portugal and Spain. In these countries, the internal per capita $R \& D$ expenditure in the enterprise sector was the lowest among the old Member States. In 2014, Greece had just over 46 euro per capita, Portugal over 99 euro and Spain nearly 146 euro. The positive feature of the analyzed meter in these three countries was a slight but systematic increase in the following years. In 2018 it reached the level of nearly 98 euro, which means an increase of 111.5 p.p. compared to 2014. In Portugal the increase was 36.6 p.p. and in Spain 24 p.p.

Among the old Member States, the EU's GERD was below the average value of the analyzed meter: Greece, Spain, Portugal and Italy. A similar situation took place in the United Kingdom, but only in 2017 and 2018.

The situation was much worse in the group of the new member states, because in each of them the $R \& D$ expenditures expressed in euro/inhabitant did not match the European average. Among these countries, Slovenia, the Czech Republic and then Hungary and Estonia stood out. In 2014 in Slovenia, the GERD meter was just over 334 euro/inhabitant and was 25.4 euro lower than the EU average. In the following three years, its value decreased to 290.4 euro in 2017 , i.e. by 13.1 p.p. In 2018 , the meter increased by 10.3 p.p. compared to the previous year. However, these results place Slovenia only 12th among the Member States.

The worst results among the new Member States were achieved by Latvia, Romania, Cyprus and Bulgaria. The average value of national R\&D spending in these countries was respectively: $20.9 ; 22.1 ; 37.3$ and 39.0 euro per capita respectively. 
Table 2. National R\&D spending (GERD) in the enterprise sector in 2014-2018 (in euro per capita)

\begin{tabular}{|c|c|c|c|c|c|}
\hline \multirow{2}{*}{ Specification } & \multicolumn{5}{|c|}{ The amount of expenditure in years: } \\
\hline & 2014 & 2015 & 2016 & 2017 & 2018 \\
\hline European Union (EU-28) & 359.5 & 382.0 & 390.9 & 412.8 & $438.0(\mathrm{p})$ \\
\hline \multicolumn{6}{|l|}{ Old EU-15 Member States: } \\
\hline Austria & 860.9 & 873.4 & 898.6 & 899.2 & $969.9(\mathrm{p})$ \\
\hline Belgium & 597.1 & 629.7 & 658.2 & 734.1 & $786.5(\mathrm{p})$ \\
\hline Denmark & 877.6 & 935.4 & 998.3 & $1,003.0$ & $1,016.0(\mathrm{p})$ \\
\hline Finland & 808.9 & 739.7 & 711.0 & 732.0 & 766.7 \\
\hline France & 470.5 & 477.8 & 485.1 & 494.5 & $505.9(\mathrm{p})$ \\
\hline Greece & 46.2 & 51.7 & 68.7 & 92.3 & $97.7(\mathrm{p})$ \\
\hline Spain & 145.9 & 149.0 & 153.4 & 166.1 & 181.0 \\
\hline The Netherlands & 441.7 & 453.8 & 485.6 & 498.0 & $653.6(\mathrm{p})$ \\
\hline Ireland & 454.3 & 477.4 & 485.2 & 579.0 & $575.1(\mathrm{p})$ \\
\hline Luxembourg & 615.6 & 607.2 & 647.8 & 680.6 & $674.4(\mathrm{p})$ \\
\hline Germany & 705.7 & 750.7 & 764.5 & 833.6 & $870.9(\mathrm{p})$ \\
\hline Portugal & 99.4 & 99.9 & 111.8 & 126.4 & $135.8(\mathrm{p})$ \\
\hline Sweden & 946.2 & 1048.3 & 1069.5 & 1151.9 & 1092.0 \\
\hline Great Britain & 384.3 & 443.7 & 414.8 & 399.2 & $430.5(\mathrm{p})$ \\
\hline Italy & 203.1 & 212.0 & 232.2 & 244.9 & $252.2(\mathrm{p})$ \\
\hline \multicolumn{6}{|l|}{ New EU-13 Member States: } \\
\hline Bulgaria & 30.8 & 44.3 & 38.4 & 38.5 & $43.1(\mathrm{p})$ \\
\hline Croatia & 38.6 & 45.4 & 44.3 & 49.3 & $58.7(\mathrm{p})$ \\
\hline Cyprus & 23.3 & 23.0 & 43.1 & 47.9 & $49.4(\mathrm{p})$ \\
\hline Czech Republic & 164.5 & 167.5 & 171.7 & 204.0 & $233.9(\mathrm{p})$ \\
\hline Estonia & 94.9 & 106.1 & 105.8 & 109.2 & $117.4(p)$ \\
\hline Lithuania & 39.5 & 36.5 & 39.7 & 49.0 & $53.0(\mathrm{p})$ \\
\hline Latvia & 28.9 & 18.9 & 13.7 & 19.2 & $23.9(\mathrm{p})$ \\
\hline Malta & 77.9 & 83.5 & 80.7 & 93.6 & 84.4 \\
\hline Poland & 47.3 & 52.9 & 71.1 & 82.1 & $104.7(\mathrm{p})$ \\
\hline Romania & 12.0 & 17.3 & 22.9 & 27.3 & 31.1 \\
\hline Slovakia & 45.5 & 47.8 & 59.5 & 74.6 & 74.6 \\
\hline Slovenia & 334.1 & 315.4 & 297.8 & 290.4 & $320.3(p)$ \\
\hline Hungary & 103.5 & 112.6 & 103.4 & 124.8 & 158.6 \\
\hline USA & 804.7 & 999.0 & $1,047.0$ & $1,080.0$ & - \\
\hline
\end{tabular}

(p) - preliminary data (provisional)

Source: own elaboration on the basis of Eurostat Data Explorer https://appsso.eurostat.ec.europa.eu/nui/print.do 
In comparison to the Member States, Poland ranked relatively low, for which in 2014 the analyzed GERD meter was just over 47 euro/inhabitant. In this respect, Poland was ranked 20th in 2014; 2015 and 2016; 21st in 2017 and 19th in 2018 among all member states; 6th in 2014-2017 and 5th in 2018 among the new member states. Compared to the average results for the EU, the internal R\&D expenditures (in euro/inhabitant) in Poland in the enterprise sector were lower by 312.2 euro in 2014; by 329.1 euro in 2015; by 319.8 euro in 2016; by 330.7 euro in 2017 and by 333.3 euro in 2018 . On the positive side, the value of the analyzed meter is growing in the following years of the analysis, as in 2018 it increased by 121.3 p.p. compared to 2014 .

\section{The development of the GERD meter in the government sector}

Another cross-section of the analysis is the level and dynamics of national spending on R\&D (GERD) incurred in the government sector per capita. The government sector consists of (Frascati Manual 2015, p. 35):

- all central/federal, regional/state and local/municipal government units, including social security institutions, with the exception of those units that correspond to the description of higher education institutions;

- other public administration bodies: agencies performing or financing R\&D and all non-market non-commercial institutions which are controlled by government units and which do not themselves belong to the higher education sector.

The size of these expenditures, expressed in euro/inhabitant, is shown in Table 3. In the period 2014-2018, they amounted to 68.7 euro/inhabitant on average in the EU. A characteristic feature of this meter is its relatively stable level in subsequent years of analysis. Year by year the dynamics of changes was as follows: In 2015, this meter increased by less than 3 p.p.; in 2016 , it decreased by 3.3 p.p., increased by 3.4 p.p. in 2017 , and increased by 1.4 p.p. in 2018 . 
Table 3. National spending on research and development (GERD) in the government sector in 2014-2018 (in euro per capita)

\begin{tabular}{|c|c|c|c|c|c|}
\hline \multirow{2}{*}{ Specification } & \multicolumn{5}{|c|}{ The amount of expenditure in years: } \\
\hline & 2014 & 2015 & 2016 & 2017 & 2018 \\
\hline European Union (EU-28) & 67.4 & 69.4 & 67.1 & 69.4 & $70.4(\mathrm{p})$ \\
\hline \multicolumn{6}{|l|}{ Old EU-15 Member States: } \\
\hline Austria & 55.0 & 56.0 & 90.7 & 91.9 & $99.2(\mathrm{p})$ \\
\hline Belgium & 76.9 & 82.7 & 92.5 & 98.1 & $105.9(\mathrm{p})$ \\
\hline Denmark & 31.6 & 32.9 & 34.0 & 46.1 & $47.5(\mathrm{p})$ \\
\hline Finland & 103.3 & 90.7 & 88.1 & 95.8 & 97.1 \\
\hline France & 93.1 & 95.7 & 94.7 & 94.6 & $96.7(\mathrm{e})$ \\
\hline Greece & 37.8 & 44.1 & 40.7 & 41.9 & $45.1(\mathrm{p})$ \\
\hline Spain & 51.8 & 54.3 & 52.8 & 53.6 & 53.9 \\
\hline The Netherlands & 93.4 & 96.7 & 94.0 & 95.1 & $56.4(\mathrm{p})$ \\
\hline Ireland & 28.1 & 29.1 & 28.4 & 29.8 & 32.9 \\
\hline Luxembourg & 342.1 & 350.6 & 314.8 & 291.0 & $287.9(\mathrm{e})$ \\
\hline Germany & 152.5 & 153.8 & 154.8 & 163.4 & $170.3(\mathrm{e})$ \\
\hline Portugal & 13.4 & 14.0 & 12.1 & 13.7 & $15.2(\mathrm{p})$ \\
\hline Sweden & 52.9 & 51.4 & 52.3 & 58.5 & 55.9 \\
\hline Great Britain & 42.8 & 44.6 & 40.5 & 38.5 & $38.1(\mathrm{p})$ \\
\hline Italy & 48.7 & 47.9 & 48.0 & 48.5 & $51.5(\mathrm{p})$ \\
\hline \multicolumn{6}{|l|}{ New EU-13 Member States: } \\
\hline Bulgaria & 11.6 & 12.5 & 11.1 & 12.7 & $13.3(\mathrm{p})$ \\
\hline Croatia & 20.9 & 21.8 & 20.4 & 22.8 & $24.4(\mathrm{p})$ \\
\hline Cyprus & 14.4 & 13.1 & 12.3 & 12.9 & $12.8(\mathrm{p})$ \\
\hline Czech Republic & 53.5 & 62.9 & 51.0 & 56.0 & $61.7(\mathrm{p})$ \\
\hline Estonia & 23.9 & 24.9 & 23.5 & 27.2 & $31.7(\mathrm{p})$ \\
\hline Lithuania & 21.8 & 22.8 & 29.6 & 37.1 & $30.2(\mathrm{p})$ \\
\hline Latvia & 19.5 & 19.6 & 17.8 & 18.5 & $21.9(\mathrm{p})$ \\
\hline Malta & 14.1 & 26.8 & 1.7 & 1.3 & 1.9 \\
\hline Poland & 24.3 & 27.7 & 2.7 & 2.9 & $3.1(\mathrm{p})$ \\
\hline Romania & 12.4 & 15.1 & 13.8 & 15.6 & 16.1 \\
\hline Slovakia & 35.0 & 47.7 & 25.3 & 28.7 & 29.3 \\
\hline Slovenia & 52.5 & 55.9 & 52.9 & 53.6 & $58.5(\mathrm{p})$ \\
\hline Hungary & 19.9 & 20.4 & 18.7 & 21.4 & 22.8 \\
\hline USA & 127.8 & 153.5 & 146.6 & 143.9 & - \\
\hline
\end{tabular}

(p) - preliminary data (provisional)

(e) - estimated data

Source: own elaboration on the basis of Eurostat Data Explorer, https://appsso.eurostat.ec.europa.eu/nui/print.do 
In the Member States, the highest values were achieved in Luxembourg with an average of 317.3 euro per capita and in Germany with 159 euro per capita. While Germany recorded a slight increase in this meter in the following years of the analysis, in Luxembourg it decreased to nearly 288 euro per capita in 2018. Compared to 2014, it therefore fell by 15.8 percentage points.

In terms of national R\&D spending in the government sector, the worst results were recorded in Portugal, with an average of 13.7 euro per capita, and in Ireland, with an average of 29.7 euro per capita. In these countries, the dynamics of this meter increased or decreased slightly in subsequent years of the analysis. Compared to 2014, in 2018 it increased by 13.4 p.p. in Portugal and by 17.1 p.p. in Ireland.

Overall, among the old Member States in 2014 and 2015, 6 countries achieved above the EU average: Luxembourg, Germany, Finland, the Netherlands, France and Belgium. In 2016, 2017 and 2018, Austria joined them, while in 2018 the Netherlands dropped by 14 euro per capita compared to the EU average.

In the new Member States, the GERD meter level in the government sector clearly differed from the EU average. Only the Czech Republic and Slovenia stood out positively from the other countries. In the Czech Republic, the average R\&D spending in the government sector was EUR 57 per capita, almost EUR 12 below the EU average, while in Slovenia, it was EUR 54.7 per capita, which was 14 euro below the EU average.

In Poland the analyzed meter was on average 12.1 euro/inhabitant. This result is lower than the EU average by 56.6 euro. In particular years the expenses incurred in Poland were lower by 43.1 euro/inhabitant in 2014; by 41.7 euro in 2015 ; by 64.4 euro in 2016 ; by 66.5 euro in 2017 and by 67.3 euro in 2018 compared to the EU average. Since 2015, the existing gap has widened to reach 25.6 euro/inhabitant in 2018. A characteristic feature of Poland is a sharp decline in $\mathrm{R} \& \mathrm{D}$ spending in the government sector per capita from 27.7 euro in 2015 to only 2.7 euro in 2016, i.e. by 25 euro and a minimal increase in subsequent years to just over 3 euro in 2018 . The result of the relatively low level of the GERD meter is Poland's distant position among the member states. In the years 2014-2015 it was 18th and in 2016-2018 - 27th place. In the group of new member states Poland was in 4th and 12th position. In the years 2016-2018, only Malta achieved worse results. 


\section{The development of the GERD meter in the higher education sector}

Another cross-section of the analysis is the level and dynamics of national R\&D expenditures (GERD meter) incurred in the higher education sector per capita. The higher education sector includes (Frascati Manual 2015, p. 36):

- all universities, technical universities and other institutions providing formal higher education programmes, regardless of their source of funding and legal status,

- all research institutes, centers, experimental stations and clinics which conduct R\&D activities under direct control or management of higher education institutions.

As can be seen from Table 4, in 2014 these expenses were more than 130 Euros/inhabitant. In the following years they changed slightly to increase by 9.6 p.p. in 2018 compared to 2014 . On average, it was 136.6 euro/inhabitant in the period under review.

The GERD meter has changed significantly across Member States. The highest values were in Denmark and Sweden, averaging 493.7 (357.1 euro per capita more than the EU average) and 403.3 euro per capita (266.7 euro more than the EU average). While in Denmark the meter had a slight upward trend except in 2016, Sweden has seen increases (2016 compared to 2015), but also decreases in $R \& D$ spending. This is the case in 2015 , when the GERD meter decreased by 1.7 p.p. compared to 2014 and 2017 and 2018. In 2017, R\&D spending decreased by 2.3 p.p. compared to 2016 and in 2018 by 2.9 p.p. compared to 2017 .

The countries that stand out, i.e. those that incur higher than EU averages expenditure on R\&D in the higher education sector, included: Austria with an average of 291.7 euro per capita (up by 155.1 euro); Finland with an average of 278.9 euro per capita (up by 142.3 euro); Netherlands with an average of 259.1 euro per capita (up by 122.5 euro); Luxembourg with an average of 227.4 euro per capita (up by 90.8 euro); Germany — average 202 euro/inhabitant (more by 65.4 euro); Belgium — average 197.2 euro/inhabitant (more by 60.6 euro); Ireland — average 160.3 euro/inhabitant 
Table 4. National spending on research and development (GERD) in the higher education sector in 2014-2018 (in euro per capita)

\begin{tabular}{|c|c|c|c|c|c|}
\hline \multirow{2}{*}{ Specification } & \multicolumn{5}{|c|}{ The amount of expenditure in years: } \\
\hline & 2014 & 2015 & 2016 & 2017 & 2018 \\
\hline European Union (EU-28) & 130.5 & 137.4 & 134.9 & 137.3 & $143.1(\mathrm{p})$ \\
\hline \multicolumn{6}{|l|}{ Old EU-15 Member States: } \\
\hline Austria & 286.1 & 287.5 & 284.4 & 288.8 & $311.5(\mathrm{p})$ \\
\hline Belgium & 176.4 & 183.0 & 203.0 & 207.4 & $216.0(\mathrm{p})$ \\
\hline Denmark & 461.4 & 500.2 & 496.6 & 497.7 & $512.6(\mathrm{p})$ \\
\hline Finland & 273.2 & 270.6 & 271.5 & 284.8 & 294.5 \\
\hline France & 149.4 & 164.9 & 153.1 & 156.7 & $158.6(\mathrm{e})$ \\
\hline Greece & 50.6 & 59.3 & 51.9 & 53.6 & $57.6(\mathrm{p})$ \\
\hline Spain & 77.5 & 79.7 & 78.6 & 81.9 & 84.6 \\
\hline The Netherlands & 253.3 & 259.9 & 253.5 & 263.8 & $264.8(\mathrm{p})$ \\
\hline Ireland & 147.5 & 163.3 & 172.9 & 156.5 & 161.1 \\
\hline Luxembourg & 188.1 & 218.8 & 235.5 & 248.5 & $246.0(\mathrm{e})$ \\
\hline Germany & 184.9 & 189.0 & 202.3 & 209.4 & $224.3(\mathrm{e})$ \\
\hline Portugal & 97.6 & 98.1 & 103.3 & 106.7 & $112.2(\mathrm{p})$ \\
\hline Sweden & 408.9 & 401.8 & 412.2 & 402.7 & 391.1 \\
\hline Great Britain & 152.1 & 170.2 & 150.0 & 140.1 & $140.3(\mathrm{p})$ \\
\hline Italy & 95.7 & 93.0 & 92.3 & 92.6 & $95.6(\mathrm{p})$ \\
\hline \multicolumn{6}{|l|}{ New EU-13 Member States: } \\
\hline Bulgaria & 4.1 & 3.3 & 2.7 & 3.1 & $3.3(\mathrm{p})$ \\
\hline Croatia & 20.6 & 21.5 & 31.3 & 29.9 & $39.2(\mathrm{p})$ \\
\hline Cyprus & 50.9 & 50.3 & 46.4 & 53.1 & $56.1(\mathrm{p})$ \\
\hline Czech Republic & 74.7 & 76.8 & 57.4 & 63.7 & $81.1(\mathrm{p})$ \\
\hline Estonia & 96.5 & 95.2 & 73.0 & 91.7 & $123.5(\mathrm{p})$ \\
\hline Lithuania & 66.7 & 74.1 & 44.2 & 46.9 & $54.5(\mathrm{p})$ \\
\hline Latvia & 33.0 & 38.1 & 24.5 & 33.0 & $50.4(\mathrm{p})$ \\
\hline Malta & 49.0 & 52.2 & 47.9 & 48.3 & 56.3 \\
\hline Poland & 29.6 & 32.8 & 34.0 & 41.8 & $50.2(\mathrm{p})$ \\
\hline Romania & 4.4 & 6.9 & 4.7 & 5.1 & 5.1 \\
\hline Slovakia & 42.6 & 74.9 & 32.7 & 34.0 & 33.5 \\
\hline Slovenia & 45.2 & 42.1 & 42.6 & 43.5 & $51.5(\mathrm{p})$ \\
\hline Hungary & 19.5 & 18.6 & 15.6 & 22.7 & $26.7(\mathrm{e})$ \\
\hline USA & 147.2 & 181.5 & 189.5 & $192.7(\mathrm{p})$ & - \\
\hline
\end{tabular}

(p) — preliminary data (provisional)

(e) - estimated data

Source: own elaboration on the basis of Eurostat Data Explorer, https://appsso.eurostat.ec.europa.eu/nui/print.do 
(more by 23.7 euro); France - average 156.5 euro/inhabitant (more by 19.9 euro) and the United Kingdom - average 150.5 euro/inhabitant (more by 13.9 euro). In the remaining countries of the old EU, i.e. Portugal, Italy, Spain and Greece, the GERD meter was lower than the EU average. However, slight upward trends were recorded only in Portugal. The lowest value of the surveyed meter was observed in Greece. On average, it was 54.6 euro/inhabitant, which was $40 \%$ of the EU average.

In terms of $R \& D$ expenditure in the higher education sector, it stood out among the new Member States: Estonia (average 96 euro/inhabitant) and the Czech Republic (average 70.7 euro/inhabitant). These results are close to the Italian and Spanish averages and are significantly lower than the EU average. At the opposite end of the scale were Bulgaria and Romania with GERD averages of 3.3 and 5.2 euro/inhabitant respectively. These results are the lowest in the whole EU.

In Poland, R\&D expenditures in the higher education sector in 2014 amounted to almost 30 euro/inhabitant, which was only $22.7 \%$ of the EU average. In subsequent years, these expenditures increased slightly yearon-year by 3.2 euro in 2015; by 1.2 euro in 2016 ; by 7.8 euro in 2017 and by 8.4 euro in 2018, representing $35.1 \%$ of the EU average. On average, in the years 2014-2018, the expenses incurred in Poland amounted to 37.7 euro per capita and were lower than the EU average result by 98.9 euro. A positive development of the GERD meter in Poland is a slight but gradual increase in the following years of the analysis, which was not always characteristic of many other countries both among old and new member states. Comparing the level of R\&D expenditures in the higher education sector in Poland with those in other Member States, it is possible to determine Poland's place in the EU. In 2014 and 2015 it was 24th in the whole EU and 9th among new Member States, in 2016 and 2017. - 22nd and 7th position, in 2018. - 23rd position in the entire EU and 8th among the new Member States. 


\section{The development of the GERD meter in the private non-profit sector}

The last cross-section of the analysis is the level and dynamics of national R\&D expenditures (GERD meter) incurred in the private nonprofit sector per capita. Private non-profit institutions have traditionally played a significant role in R\&D activities both as contractors and financiers, although generally to a lesser extent than in other economic sectors. The sector of private non-profit institutions includes (Frascati Manual 2015, pp. 36-37):

- all non-profit institutions serving households as defined in the SNA 2008, except those in the higher education sector;

- households and individuals engaged or not engaged in market activities.

The values of this meter formed in the years 2014-2018 in selected Member States, on average in the EU and in the USA are presented in Table 5. In contrast to the previous analysis cross-sections, the consideration of $R \& D$ spending in the private non-profit sector is limited due to incomplete statistical data presented by Eurostat.

As Table 5 shows, GERD values in the non-profit sector were significantly lower compared to the enterprise, government and higher education sectors. In this sector, in the years 2014-2018, on average in the EU nearly 5.0 euro per capita was spent on $R \& D$. The highest value (5.3 euro) was in 2015 and the lowest (4.7 euro) in 2017. In the Member States for which Eurostat presented figures, the level and dynamics of these expenditures varied from year to year. Among the old Member States, the GERD meter was highest in the UK and France. In the former, it averaged 12.8 euro per capita on average over the period under review, i.e. 7.8 euro more than the EU average. The lowest value, less than 11 euro per capita, was reached in 2014 and the highest 13.8 euro in 2018. Thus, a slight increase of 3.1 euro was recorded. In France, the average value of R\&D spending was 11.8 euro per capita and was 6.8 euro higher than the European average. In both these countries we can speak about a relative stability of the meter under consideration. In France, it grew in 2018 by 1.1 euro compared to 2014. 
Table 5. National spending on research and development (GERD) in the private non-profit sector in 2014-2018 (in euro per capita)

\begin{tabular}{|c|c|c|c|c|c|}
\hline \multirow{2}{*}{ Specification } & \multicolumn{5}{|c|}{ The amount of expenditure in years: } \\
\hline & 2014 & 2015 & 2016 & 2017 & 2018 \\
\hline European Union (EU-28) & 4.8 & 5.3 & 5.1 & 4.7 & $5.0(\mathrm{p})$ \\
\hline \multicolumn{6}{|l|}{ Old EU-15 Member States: } \\
\hline Austria & 5.7 & 6.0 & 6.3 & 7.0 & $7.6(\mathrm{p})$ \\
\hline Belgium & 3.9 & 4.9 & 5.8 & 5.8 & $6.6(\mathrm{p})$ \\
\hline Denmark & 5.6 & 5.2 & 5.4 & 4.6 & $4.8(\mathrm{p})$ \\
\hline Finland & 9.2 & 8.6 & 9.3 & 9.2 & 9.5 \\
\hline France & 11.2 & 11.5 & 12.2 & 12.0 & $12.3(\mathrm{e})$ \\
\hline Greece & 1.7 & 1.8 & 1.4 & 1.5 & $2.0(\mathrm{p})$ \\
\hline Spain & 0.5 & 0.6 & 0.7 & 0.6 & 0.8 \\
\hline The Netherlands & - & - & - & - & - \\
\hline Ireland & - & - & - & - & - \\
\hline Luxembourg & - & - & - & - & - \\
\hline Germany & - & - & - & - & - \\
\hline Portugal & 3.7 & 3.4 & 3.7 & 3.9 & $4.3(\mathrm{p})$ \\
\hline Sweden & 3.4 & 2.8 & 3.0 & 1.9 & 1.7 \\
\hline Great Britain & 10.7 & 13.5 & 13.0 & 13.0 & $13.8(\mathrm{p})$ \\
\hline Italy & 10.9 & 11.6 & 9.5 & 6.7 & $7.1(\mathrm{p})$ \\
\hline \multicolumn{6}{|l|}{ New EU-13 Member States: } \\
\hline Bulgaria & 0.4 & 0.3 & 0.2 & 0.5 & $0.4(\mathrm{p})$ \\
\hline Croatia & - & - & - & - & - \\
\hline Cyprus & 15.8 & 14.4 & 14.6 & 15.1 & $15.6(\mathrm{p})$ \\
\hline Czech Republic & 1.2 & 1.2 & 0.7 & 0.9 & $0.8(\mathrm{p})$ \\
\hline Estonia & 2.6 & 4.1 & 3.2 & 3.3 & $4.7(\mathrm{p})$ \\
\hline Lithuania & - & - & - & - & - \\
\hline Latvia & - & - & - & - & - \\
\hline Malta & - & - & - & - & - \\
\hline Poland & 0.3 & 0.2 & 0.5 & 0.4 & $0.5(\mathrm{p})$ \\
\hline Romania & 0.1 & 0.1 & 0.1 & 0.1 & 0.1 \\
\hline Slovakia & 0.5 & 0.7 & 0.6 & 0.6 & 0.6 \\
\hline Slovenia & 0.2 & 0.2 & 0.1 & 0.8 & $1.4(\mathrm{p})$ \\
\hline Hungary & - & - & - & - & - \\
\hline USA & 45.5 & 56.0 & 59.4 & 61.1 & - \\
\hline
\end{tabular}

(p) - preliminary data (provisional)

(e) - estimated data

Source: own elaboration on the basis of Eurostat Data Explorer, https://appsso.eurostat.ec.europa.eu/nui/print.do 
In the old Member States, Spain and Greece showed the least interest in developing $R \& D$ activities in the private non-profit sector. In the first country, R\&D expenditure averaged 0.6 euro/inhabitant and in Greece 1.7 euro. They were lower than the EU average by 4.4 euro and 3.3 euro/inhabitant respectively.

Among the new Member States, only Cyprus was distinguished by relatively high $R \& D$ expenditures in the private non-profit sector. On average, during the period under review, they amounted to 15.1 euro/inhabitant. They were higher than the EU average by 10.1 euro and the highest in the whole community. Their dynamics was rather stable.

In the other new Member States, R\&D expenditures in the non-profit sector were at a much lower level compared to the EU average. Apart from Estonia and the Czech Republic, where they ranged from 2.6 euro/inhabitant to 4.7 euro (Estonia) and 0.7 euro/inhabitant to 1.2 euro (Czech Republic) respectively, in the other countries the GERD meter did not reach 1 euro/inhabitant. In the extreme case (Romania) only 0.1 euro/inhabitant was spent on R\&D.

In Poland, the analyzed meter changed from 0.2 euro/inhabitant in 2015 to 0.5 euro in 2016 and 2018. In the analysed period an average of 0.38 euro/inhabitant was spent on $R \& D$, i.e. less by 4.6 euro than in the EU. In particular years, the expenditure on R\&D in Poland was lower than the EU average by 0.38 euro/inhabitant, i.e. less by 4.6 euro than in the EU: 4.5 euro/inhabitant in 2014 , by 5.1 euro in 2015 , by 4.6 euro in 2016, by 4.1 euro in 2017 and by 4.5 euro in 2018. The level of the analyzed meter provided Poland with 17th position in 2014, 2015 and 2018; 16th position in 2016 and 18th position in 2017 among the countries listed in Table 5, while among the new Member States it was 6 th position in 2014, 2015 and 2018; 5th position in 2016, and 7th in 2017.

\section{Summary}

A statistical-comparative analysis of R\&D expenditures in the EU and in the Member States, using the GERD meter, expressed in euro/inhabitant, leads to the following conclusions: 
- these expenditures varied in terms of size during the period in question both in the old EU member states and in the new countries,

- the nature of the dynamics of these expenditures indicates a significant degree of randomness of R\&D policy in particular sectors,

- there is a clear gap between old and new Member States. The former had much higher R\&D expenditure except for Greece and Portugal,

- the different amount of outlays incurred in particular years indicates a lack of rational R\&D policy in the sectors concerned,

- the level of R\&D expenditures in all new Member States was lower than the EU average in all analysed sections except Cyprus in the non-profit sector,

- the average level of the GERD meter in the EU was significantly lower than the average in the USA: by 751.9 euro/inhabitant in all sectors; by 396.6 euro/inhabitant in the business sector; by 74.2 euro/inhabitant in the government sector; by 41.1 euro/inhabitant in the higher education sector and by 50.5 euro/inhabitant in the non-profit sector,

- there is a clear (in minus) gap between the level of $R \& D$ investment in Poland and the average performance for the EU and most Member States, which places Poland at a distant position among the Member States,

- in terms of R\&D expenditures (average results in the EU) expressed in euro/inhabitant, the leading position is held by the enterprise sector average GERD 396.6 euro/inhabitant, followed by the higher education sector - average GERD 136.6 euro/inhabitant; government - average GERD 68.7 euro/inhabitant and non-profit — where the average GERD was only 5 euro/inhabitant.

It should be stressed that the signalled order of individual sectors in terms of per capita R\&D expenditures does not apply to all Member States. For example, in Cyprus, the GERD meter was higher in the higher education sector than in the enterprise sector. A similar situation took place in Lithuania and Latvia. There are also countries such as Luxembourg, Bulgaria, Romania and partly Hungary, where the GERD meter in the government sector was higher than in higher education.

Thus, it can be assumed that individual statistical units do not pursue a rational, long-term research and development policy, resulting in a 
systematic acquisition of new knowledge necessary to solve current and future problems occurring within individual units, at their interface with customers and in their environment. Such policy requires taking into account many legal, economic, social, organizational, technical, marketing, management, methodological and financial factors which are manifested by a sufficiently high level of expenditures and their dynamics on planned research and development works inspired by technological, social, economic and market needs in subsequent periods of time.

The above mentioned statements allow to state that the adopted objectives of the publication have been achieved.

Since the problems to be solved arise not only at the level of statistical units, but also at the local, regional and national level, it is necessary to involve governments, higher education units, enterprises and non-profit organizations in shaping coherent R\&D policy at all levels of management. It may be helpful in this respect to follow the concept proposed in Figure 2, which encourages holistic innovation in the management of statistical units.

The essence of management based on this model, which is innovation in itself (innovation in management), is based on the systemic cooperation and financial integration of institutions in the sectors (Serrano-Bedia, Lopez-Fernandez, and Garcia-Piqueres, 2010, p. 444): government, business, higher education and private non-profit organizations within a specific R\&D policy. Financial integration involves the systematic acquisition and use of financial resources (own funds, credits, subsidies, grants, tax credits, venture capital, etc.) to achieve the objectives resulting from $R \& D$ policies carried out in specific sectors and coordinated by the national policy of socio-economic development (Baruk, 2009 , p. 133). Such coordination may be facilitated by rational processes of managing R\&D activity, including the following functions: setting $R \& D$ activity goals and planning the ways of their realization, organizing, leading and controlling, carried out in particular sectors, aimed at systemic acquisition of new knowledge and its use to solve emerging problems, to create/co-create innovations being the main factor of development of each economy, increase of its competitiveness, creation of value for clients. 
Figure 2. The model of management of R\&D activity in the sectors that incur expenditures on this activity

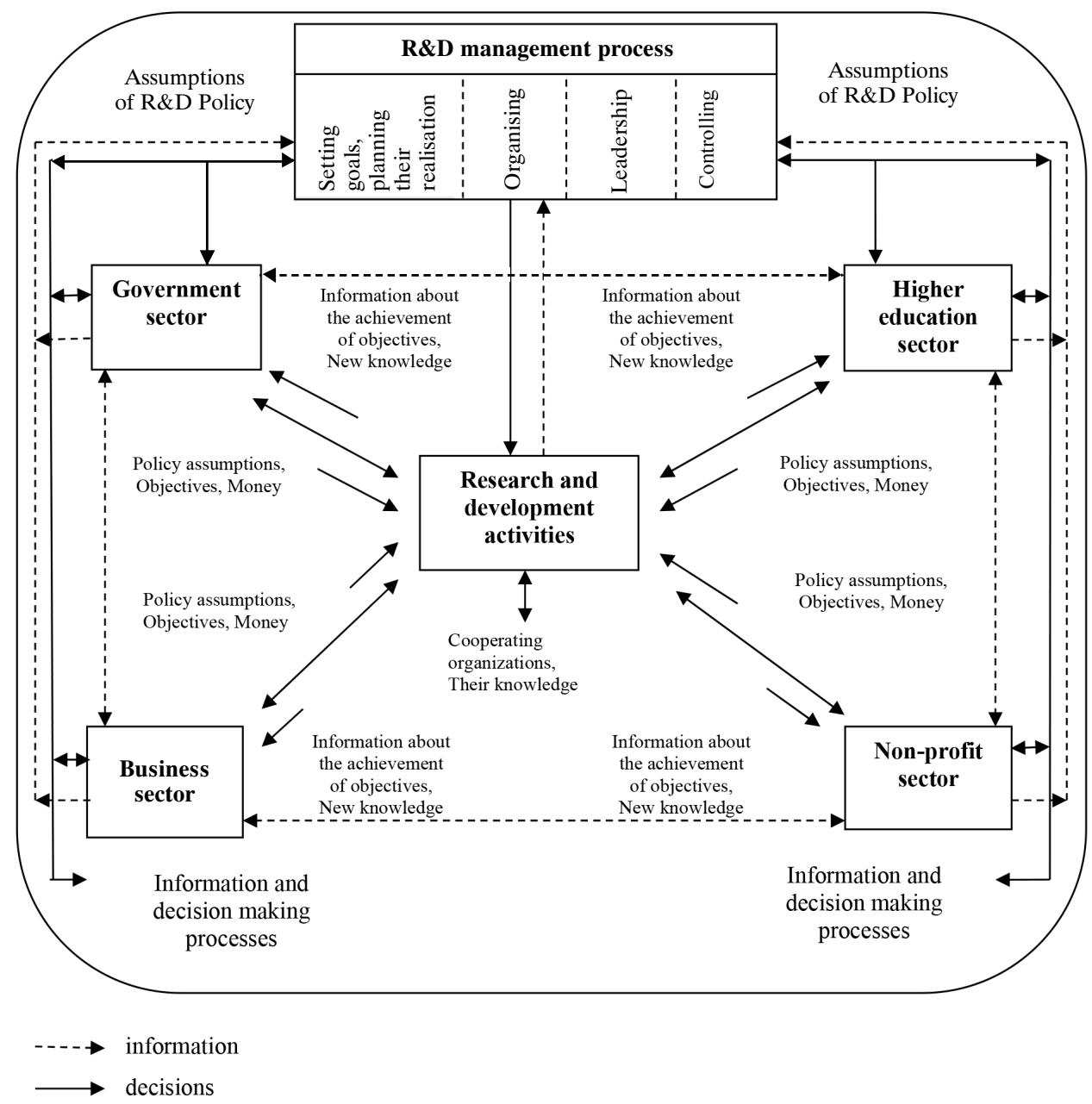

Source: own elaboration.

Innovative ways of realising management functions by managers can create an organizational context conducive to systemic creation/co-creation of new knowledge, linking it with existing knowledge and its rational use to solve emerging problems in various functional areas of statistical units, to create/cocreate and implement innovations providing customers with expected value, to transform knowledge into a competitive advantage. The innovations in 
management are conducive to overcoming all barriers accompanying $R \& D$ activity, innovative activity, barriers dependent on management. Such barriers are internal barriers, in particular (Das, Verburg, Verbraeck, and Bonebakker, 2018, p. 99): incorrectly developed strategy of the statistical unit or lack thereof, wrong organizational architecture, passive leadership, low organizational culture (Wang and Chen, 2017, p. 97), low level of R\&D organization or lack thereof, nurturing of bureaucratic structures, antimotivational incentives to achieve results, inability of the management to analyse the market systemically, behaviour of customers and competitors, technological turbulence, lack of knowledge of modern management methods, lack of ability to create an innovative experience environment, lack of understanding of the role of R\&D activity in the process of creating new knowledge and its relation to innovative activity, etc.

\section{References}

1. Arendra, P., Putri, K. A., Rumamby, I. R., \& Mercia. (2018). Analysis Influence of Knowledge Management on Innovation and Performance of Organization. International Journal of Recent Engineering Research and Development, 03(04), 18-24.

2. Baruk, J. (2009). Zarzadzanie wiedza i innowacjami. Toruń: Wydawnictwo Adam Marszałek.

3. Baruk, J. (2019). Finansowe aspekty polityki badawczej i rozwojowej w Unii Europejskiej, Marketing Instytucji Naukowych $i$ Badawczych, 33(3).

4. Bentzen, T. O., Sorensen, E., \& Torfing, J. (2020). Strengthening public service production, administrative problem solving, and political leadership through co-creation of innovative public value outcomes? The Innovation Journal: The Public Sector Innovation Journal, 25(1).

5. Das, P., Verburg, R., Verbraeck, A., \& Bonebakker, L. (2018). Barriers to innovation within large financial services firms. An in-depth study into disruptive and radical innovation projects at a bank. European Journal of Innovation Management, 21(1).

6. Deloitte Polska (2016). Badania i rozwój $w$ przedsiębiorstwach 2016. Retrieved from https://www2.deloitte.com/content/dam/Deloitte/pl/Documents/Reports/pl_RD-2016Poland-PL.pdf (accessed on 20.03.2020).

7. Ecker, B., van Triest, S., \& Williams, Ch. (2011). Management Control and the Decentralization of R\&D. Journal of Management, 39(4), https://doi.org/ 10.1177/0149206311411507

8. Eurostat Data Explorer. https://appsso.eurostat.ec.europa.eu/nui/print.do (accessed on 04.02.2020)

9. Frascati Manual 2015. (2018). Pomiar dziatalności naukowo-technicznej i innowacyjnej. Zalecenia dotyczqce pozyskiwania $i$ prezentowania danych $z$ zakresu dziatalności badawczej i rozwojowej. Warszawa: GUS. 
10. Griffin, R. W. (2007). Podstawy zarzadzania organizacjami. Warszawa: Wydawnictwo Naukowe PWN.

11. GUS (2018). Działalność badawcza i rozwojowa w Polsce $w 2017$ r. Warszawa, Szczecin: GUS.

12. Heij, C. V., Volberda, H. W., Van den Bosch, F. A. J., \& Hollen, R. M. A. (2019). How to leverage the impact of $R \& D$ on product innovation? The moderating effect of management innovation. $R \& D$ Management, 50(2). https://doi.org/10.1111/radm.12396 (accessed on 18.03.2020)

13. Knowledge-based economy. https:/www.mep.gov.sa/en/AdditionalDocuments/PlansEN/ 9th/Ninth\%20Development\%20Plan\%20-\%20Chapter\%205\%20-\%20KnowledgeBased\%20Economy\%20.pdf

14. Nguyen, T. H. \& Nhat-Hanh Le, A. (2019). Promoting creativity and innovation: expectedand unexpected consequences. Asia Pacic Journal of Innovation and Entrepreneurship, 13(3).

15. Oslo Manual 2018 (2018). Guidelines for Collecting, Reporting and Using Data on Innovation, 4th Edition. OECD.

16. Peters, Th. J. \& Waterman, R. H. (2000). Poszukiwanie doskonatości w biznesie. Warszawa: Wydawnictwo MEDIUM.

17. Serrano-Bedia, A. M., Lopez-Fernandez, M. C., \& Garcia-Piqueres, G. (2010). Decision of institutional cooperation on R\&R. European Journal of Innovation Management, 13(4).

18. Skrodzka, I. (2015). Development of knowledge-based economy in European Union in 2000-2014. Quantitative Methods in Economics, XVI(2).

19. Suomala, P., \& Jokioinen, I. (2003). The patterns of success In product development: a case study. European Journal of Innovation Management, 6(4).

20. Wang, T. \& Chen, M. (2017). Perceiving Organisational Culture Influence on Knowledge Management Performance. Science Journal of Business and Management, 5(3).

21. Xie, Z., Hall, P., McCarthy, J. I., Skitmore, M., \& Shen, L. (2016). Standardization efforts: The relationship between knowledge dimensions, search processes and innovation outcomes. Technovation, 48-49.

Jerzy Baruk, PhD, Eng., Maria Curie-Skłodowska University in Lublin, Poland - a retired academic of the Institute of Marketing and Management of the Faculty of Economics at the Maria Curie-Skłodowska University in Lublin. His research work focuses on the organisational and economic aspects of innovation activities, innovation management and management through innovation, as well as the impact of innovation on the efficient functioning of organisations. Knowledge management and the relationship between the management of knowledge and innovation creation constitutes another area of his research work. Author of over 380 scientific publications on the broader aspects of innovation and knowledge management published in domestic and international scientific journals and conference materials. Author of four books and numerous other co-authored publications. He has also presented the results of his scholarly work and research at many domestic and international conferences. A fellow of the following learned organisations: Scientific Society of Organization and Management; Polish Association for Production Management; "Taures" Economic Initiative Enterprise in Warsaw; Lublin Scientific Society; Polish Praxeological Society; University — Industry - Science Partnership; Polish UNISPAR Working Group Society; Innovative Entrepreneurs' Club at the Lublin Development Foundation. Advisor in the Lublin Branch of the Scientific Society for Organization and Management as well as the "Taures" Economic Initiative Enterprise in Warsaw. 